\title{
A Framework for Exploring the Degree of Hybridity in Social Entrepreneurship
}

\begin{tabular}{|r|l|}
\hline Journal: & Academy of Management Perspectives \\
\hline Manuscript ID & AMP-2018-0013.R3 \\
\hline Document Type: & Article \\
& $\begin{array}{l}\text { New venture strategies < Entrepreneurship < Topic Areas, } \\
\text { Organizational life cycle (e.g. birth, survival, growth, death) }< \\
\text { Entrepreneurship < Topic Areas, Entrepreneurship (General) }< \\
\text { Entrepreneurship < Topic Areas, Decision-making < Managerial and } \\
\text { Organizational Cognition < Topic Areas, Decision-making < Organization } \\
\text { and Management Theory < Topic Areas, Identity < Organization and } \\
\text { Management Theory < Topic Areas }\end{array}$ \\
\hline
\end{tabular}




\title{
A Framework for Exploring the Degree of Hybridity in Entrepreneurship
}

\author{
Dean A. Shepherd \\ University of Notre Dame \\ dshephe1@nd.edu \\ Trenton Alma Williams \\ Indiana University \\ trenwill@iu.edu \\ Eric Yanfei Zhao \\ Indiana University \\ ericzhao@indiana.edu
}

\begin{abstract}
Aknowledgements
We thank Mike Wright and an anonymous reviewer for their helpful suggestions on previous versions of this manuscript. The second author acknowledges the financial support of the Handelsbanken's Research Foundation, with which some of this research was supported. We also thank Ali Ferguson for her helpful support in preparing and finalizing the manuscript.
\end{abstract}




\begin{abstract}
In this paper, we problematize the growing literature on hybrid organizing to demonstrate that research on hybrids and entrepreneurship can benefit from considering the degree of hybridity in organizing the exploitation of potential opportunities for the creation of both economic and social value. Recent work has moved beyond discrete categorization of organizations as hybrid (or not) to conceptualize hybridity as a continuum anchored by a strong social logic at one end and a strong economic logic at the other end. We take the conceptualization of hybridity one step further by acknowledging that organizations can differ in the relative importance they ascribe to the economic logic vis-à-vis the social logic and that both the economic and social logics can be held at varying levels of intensity. The main purpose of revising the conceptualization of the degree of hybridity is to develop a framework for future research. This framework highlights the importance of understanding how entrepreneurs can both directly and indirectly (through the coconstruction of potential opportunities) influence the degree of hybridity, and how differences in degree of hybridity impact organizational outcomes in terms of success and failure in creating economic and social value.
\end{abstract}

Keywords: hybrid organizing; hybridity; social entrepreneurship; entrepreneur; opportunity; community of inquiry; co-construction 
Entrepreneurship research has largely placed organizations into one of three categorieseconomic, social", and a combination of the two called "hybrid" (Battilana, Sengal, \& Pache, 2015; Fosfuri, Giarrantana \& Roca, 2016; Katre \& Salipante, 2012; McMullen \& Warnick, 2016; Miller et al., 2012). Studies of hybrid organizations have gained prominence in recent years (Battilana \& Lee, 2014), growing into a major stream of research in management and entrepreneurship scholarship. As argued in a recent review (Battilana, Besharov, \& Mitzinneck, 2017), this growing body of literature can be loosely classified into three primary approaches: hybrid rationales operating at the extra-organizational level, hybrid forms operating at the organizational level, and hybrid identities operating at the intra-organizational level. Collectively, these three approaches have advanced our understanding of (1) how rival institutional logics are infused into hybrid organizing and thus lead to potential tensions and conflicts among internal and external constituencies (Battilana \& Dorado, 2010; Pache \& Santos, 2013); (2) how the nature and strengths of challenges, internal/contextual tensions, and conflicts variably manifest at the organizational level (Cobb, Wry, \& Zhao, 2016; Williams et al., 2017; Wry \& Zhao, 2018; Zhao \& Wry, 2016) and how hybrid organizations succeed or struggle in using various means to manage such conflicts and assuage tensions (Battilana et al., 2015; Smith \& Tracey, 2016); and (3) how different identity elements are integrated in the creation and strategic orientation of hybrid organizations (Besherov, 2014; Smith \& Besherov, 2018; Wry \& York, 2017)

Notwithstanding their unique focus and insights, these past studies share a common premise: they tend to view hybrid organizations as a distinct organizational type that differs from

\footnotetext{
${ }^{1}$ Hybrid organizations could include a number of combinations beyond economic and social. For example, prior research has explored additional hybrid forms that combine economic outcomes with other objectives, such as environmental sustainability (Shepherd \& Patzelt, 2011), community well-being (Peredo \& Chrisman, 2006), alleviation of suffering (Williams \& Shepherd, 2016a; Williams et al., 2017), and even state-owned enterprises (Bruton, Peng, Ahlstrom, Stan, \& Xu, 2015). For the purposes of this paper, we refer to non-economic orientations as "social" while also recognizing the presence of other orientations.
} 
traditional organizational forms in that hybrid organizations mix "two or more organizational elements that would not conventionally go together" (Battilana, et al., 2017: 129). While acknowledging such qualitative differences between hybrids and non-hybrids is useful, doing so risks overly simplifying the potential heterogeneity among the hybrids, thus underplaying the impact of different degrees of hybridity across organizations. To address this issue, Battilana and colleagues (2017) call for future research based on a view of hybridity as a matter of degree rather than type. Battilana and colleagues' (2017) take an initial step in the direction of conceptualizing the degree of hybridity by highlighting that the economic logic and the social logic are ends of a continuum. This argument is important as it moves beyond the coarse categorical conceptualization of organizations (e.g., social, economic, or hybrid) and acknowledges variability in the nature of logics within hybrid organizations that likely shapes venture outcomes.

In this study, we build on and extend Battilana and colleagues' (2017) efforts and argue that we should go beyond the notion of hybridity as a continuum and instead theorize on the degree of hybridity, which involves the relative importance of the economic logic vis-à-vis the social logic (i.e., from an unbalanced emphasis on the economic logic to a balanced emphasis on both logics to an unbalanced emphasis on the social logic) as well as the intensity of the logics (i.e., low to high intensity). We propose that the degree of hybridity is shaped by the central elements of organizational emergence: (1) the entrepreneur, such as the entrepreneur's prosocial motivation and social-based affect; (2) the community of inquiry, or the "potential stakeholders that provide feedback on the veracity of a potential opportunity" (Shepherd, 2015: 491); (3) the nature of the potential opportunity to create some level of both economic and social value; and (4) the organizational outcomes - the level of success and failure of ventures with different 
degrees of hybridity. Indeed, the main purpose of this paper is to use our revised conceptualization of the degree of hybridity to create a framework for future research that motivates and informs a fresh examination of the relationships between entrepreneurship and hybrid organizing.

Importantly, the objective of this study is less about conducting a comprehensive review (i.e., a paper suited for the Academy of Management Annals). Rather, we problematize core premises of the literature and offer insights into potential solutions. Specifically, in the following sections, we provide detail on our reconceptualization of the degree of hybridity and then use that reconceptualization in a framework to offer an agenda for future research that can advance scholarship on hybrid organizing and entrepreneurship.

\section{HYBRID ORGANIZING}

\section{Social-Economic Tension in Hybrid Organizing}

Hybrid organizing refers to "activities, structures, processes and meanings by which organizations make sense of and combine aspects of multiple organizational forms" (Battilana \& Lee, 2014: 398). Hybridity has been defined as "the mixing of core organizational elements that would not conventionally go together" (Battilana et al., 2017: 129). Therefore, effective hybrid organizing involves incorporating the multiple core elements (Hannan \& Freeman, 1984), including identities, forms, and rationales, that define core organizational processes and associated goals (Wry \& York, 2017). The hybrid organizing literature has (until recently) typically assumed that organizations primarily serve either an economic or a social functiontwo "pure" forms that compete when combined in a hybrid organization (Jay, 2013; Pache \& Santos, 2013). Hybrid organizations experience tensions between social and economic orientations, in which there is a competition for core business activity functions. These tensions 
can lead to disruptions in resource allocation (Smith, Gonin, \& Besharov, 2013), inter-personal conflict that decreases organizational efficiency (Fiol et al., 2009), and decision-making paralysis (Pache \& Santos, 2010). Indeed, prior research has demonstrated the long-term impact of the economic-social tension, highlighting the risk of "mission drift" (i.e., unintended divergence from a stated mission or core objective) that can occur when conflict-reconciliation processes result in action that is inconsistent with stated strategic objectives (Ben-Ner, 2002; Ebrahim, et al., 2014; Grimes, Williams, \& Zhao, 2018).

Despite the potential issues associated with reconciling hybrid tensions, other research (Tobias et al., 2013) has found that economic and social value creation are often intertwined such that entrepreneurial venturing removes economic and social problems for both the entrepreneur and others within society. That is, Tobias and colleagues (2013) find that economic and social objectives appear to be complementary rather than competing. This finding is consistent with other research showing that hybrid objectives reinforce one another, such as work on multinational corporations entering bottom-of-the-pyramid markets (Simanis \& Hart, 2008; London \& Hart, 2004), organizations seeking to respond to audiences with complex demands (Paolella \& Durand, 2016), staffing creativity in recognizing underutilized assets (Hockerts, 2015), and community-based enterprises (Peredo \& Chrisman, 2006). At the very least, these findings suggest that hybrid organizing is perhaps more nuanced than previously understood and that the coarse way in which it has been defined and measured might have contributed to the mixed and competing findings.

\section{Hybridity as a "Matter of Degree"}

More recent work on hybridity (Battilana et al., 2017: 129) has proposed that future studies should further problematize the notion of hybridity and treat it as a "matter of degree." A 
simple way to treat hybridity as a matter of degree is to conceptualize it as a continuum anchored by an economic logic at one end and a social logic at the other end. Along such a continuum, hybridity would tend to be greatest in the middle. Although this continuum is an improvement from the dichotomous economic-social conceptualization, it does not capture the intensity of hybridity. For example, based on the continuum conceptualization of hybridity, a firm with a moderately weak economic logic and a moderately weak social logic would be considered the same degree of hybridity as a firm with a strong economic logic and a strong social logic. Yet, ventures with a strong economic or social logic have a more intense hybridity that likely presents different challenges and benefits than the low hybrid intensity ventures. As this comparison demonstrates, the degree of hybridity is likely broad in scope (even in the middle of the simple economic-social continuum). Differences in the intensity of hybridity are likely to impact important problems and solutions, such as whether and how economic-social tension presents in hybrid organizations and whether and how it can be resolved. Furthermore, these differences suggest the need for greater precision in theorizing and measurement to advance scholarship on hybrid organizing.

\section{A Revised Conceptualization of Hybridity}

In a step toward offering a more nuanced representation of hybridity as called for by recent scholars (Battilana et al., 2017; Battilana \& Lee, 2014) and in an effort to acknowledge the complexity and variety of hybrid forms, we offer a conceptualization of hybridity in Figures 1a-1c. Consistent with prior scholarship, our conceptualization acknowledges and accounts for the "multiple elements" (Battilana et al., 2017: 149) present in hybrid organizing across a continuum. However, in extending these conceptualizations of the "degree of hybridity," we seek to account for differences in the relativity (i.e., distribution) and intensity (i.e., prominence) of 
potentially competing hybrid logics within a firm. We now turn to a discussion of these two components, which we argue constitute the degree of hybridity.

Hybrid relativity and the degree of hybridity. Hybrid relativity refers to the extent of the distribution of multiple logics within the organization, or the way in which the economic and social logics are balanced within an organization. Organizations can vary in how they emphasize (i.e., focus attention on) multiple goals. For example, an organization could be focused primarily on economic objectives (e.g., 90\% of attention and resources) with a secondary focus on social objectives (e.g., 10\% of attention and resources). As an example of low relative hybridity, many large corporations are now engaging in highly organized corporate social responsibility (CSR) initiatives to both do good and provide goodwill for their organizations. As an illustration, Humana Inc. (a provider of Health Insurance products and services) devotes the vast majority of its efforts to generating economic returns. However, Humana also publishes a CSR annual report, which includes specific goals for positive community impact (e.g., "make the communities we serve $20 \%$ healthier by 2020 ") and highlights all of the organization's efforts to achieve positive social outcomes as a secondary objective of the firm (Humana, 2018). Thus, one might argue that Humana has low hybrid relativity because its primary orientation is on economic outcomes.

In contrast, high hybrid relativity occurs when there is parity in the representation of economic and social logics at the organization's core. For example, Emmanuel Faber, Chairman and CEO of Danone, "is very engaged in the development of new, more inclusive business models" (www.danone.com) and created Danone Communities with Mohammad Yunus to help alleviate poverty by providing people nutrition and a safe place to live (www.danonecommunities.com). Faber's goal is to ensure that economic and social goals are 
mutually reinforcing-where neither one is lost over time. To achieve this, he is altering his business model, legal way of organizing, and taking other steps in adjusting the organization's core activities to align with a hybrid orientation. In summary, this first aspect of hybridity offers a more nuanced understanding of the continuum of economic-social logics and their influence on core organizational activities.

In Figure 1a, we display a continuum for hybrid relativity. The y-axis is the relative emphasis of the social logic (vis-à-vis the economic logic) from low to high, and the $\mathrm{x}$-axis is the relative emphasis of the economic logic (vis-à-vis the social logic) from low to high. As illustrated in the Figure 1a, a traditional social venture is relatively high in social logic and low in economic logic (low hybridity), a traditional economic venture is relatively high in economic logic and low in social logic (low hybridity), and a traditional hybrid venture is balanced - the social and economic logics are relatively equal within the venture (high hybridity). We use the word traditional to reflect the previous trichotomy of organizational forms but anticipate that firms vary across this continuum (the dotted diagonal line) and that hybrid relativity increases as the relative importance of the economic and social logics becomes more balanced.

\section{------INSERT FIGURE 1A ABOUT HERE------}

Hybrid intensity and the degree of hybridity. Hybrid intensity refers to the vigor with which the economic logic is held within an organization and the vigor with which the social logic is held within an organization. For example, an organization with both strong economic and social logics experiences high hybrid intensity and will likely seek to enhance its scale to expand its social and economic missions. For example, Va Va Coffee launched a venture in 2009 with the objective of reducing the steps in the value chain connecting Kenyan specialty coffee farmers with customers. This organization is strongly committed to increasing the value captured by 
Kenyan farmers and strongly committed to generating substantial economic growth to provide a quality product that meets global coffee demands (Chhabra, 2018).

In contrast, organizations with low social and economic logics have low hybrid intensity. With both a weak social logic and a weak economic logic, these organizations likely include many lifestyle businesses, small-scale family businesses, hobby businesses, and other ventures not committed to substantially growing. While these businesses do generate an income for employees, they may also play some role in the community, providing some (albeit smaller in scale) social value. For example, a new restaurant recently opened in Decatur, Georgia that expressed these dual objectives. The founder explained, "I was raised right around the corner and went to [the local High School]. . . . I have a passion not just for food service, but also food security. I want to bring something special to this area because it's my neighborhood" (Fonville, 2018). He later explained that he wanted to provide "community support" by offering jobs to first-time job seekers and those who were formerly incarcerated. As illustrated in these examples, there is a continuum in hybrid intensity based on the vigor with which the economic and social logics are held within the organization.

In Figure 1b, we display the possible range of hybrid intensity across organizations. The $\mathrm{y}$-axis is the intensity of the social logic from low to high, and the $\mathrm{x}$-axis is the intensity of the economic logic from low to high. As illustrated in Figure 1b, a traditional social venture is considered to have high-intensity social logic but low-intensity economic logic, and a traditional economic venture is considered to have high-intensity economic logic but low-intensity social logic. In Figure 1b, we illustrate current conceptualizations of the traditional hybrid venture (based largely on relative hybridity), including hybrid ventures with low-intensity social and economic logics, hybrid ventures with moderate-intensity social and economic logics, and hybrid 
ventures with high-intensity social and economic logics. The hybrid intensity of an organization can be represented anywhere along the diagonal solid line of Figure $1 \mathrm{~b}$. Ventures high in intensity for both social and economic logics have the highest hybrid intensity.

\section{------INSERT FIGURE 1B ABOUT HERE------}

In combining the arguments above, we propose that firms' degree of hybridity will vary depending on the relativity and intensity of their hybridity. In Figure 1c, we display examples of the degree of hybridity on a y-axis of social logic intensity and an x-axis of economic logic intensity. As illustrated in the Figure 1c, the dashed line indicates relative hybridity, with low relative hybridity at the ends of the line and the highest level of relative hybridity in the middle of the line. The diagonal solid line (of Figure 1c) illustrates hybrid intensity, which increases from low hybrid intensity (i.e., low social and economic intensity) to moderate hybrid intensity (i.e., moderate social and economic intensity) to high hybrid intensity (i.e., high social and economic intensity). The ventures to the upper right of the figure have the highest degree of hybridity.

We reflect the degree of hybridity in a different way in Figure 1d. The axes are the same as for Figure 1c, but in this case, we plot points of equal degrees of hybridity. The thin curve highlights a plot of ventures with the same low degree of hybridity, the next curve indicates a plot of ventures with the same moderate degree of hybridity, and the final (thickest) curve is a plot of ventures with the same high degree of hybridity.

\section{------INSERT FIGURE 1C AND 1D ABOUT HERE------}

By conceptualizing the degree of hybridity in terms of both the relativity and intensity of the hybridity, we can begin to gain a deeper appreciation of the role of hybridity in organizations that create both economic and social value. Furthermore, we anticipate that this revised 
conceptualization offers a possible explanation for competing findings across hybrid organizing studies. For example, could it be that studies that found a tension (Jay, 2013; Pache \& Santos, 2013) between social and economic logics did so due to firms' high-relativity hybridity, highintensity hybridity, or both? Similarly, could results suggesting a complementary role of hybrid logics (Tobias et al., 2013) be due to high-relativity hybridity but moderate- or low-intensity hybridity? While the purpose of this paper is not to challenge the findings of previous studies, we do hope that a revised conceptualization of the degree of hybridity enables the development of new theories and empirical models of hybridity and organizing. Furthermore, we hope a more nuanced conceptualization of the degree of hybridity (i.e., the combination of both the relativity and intensity of the hybridity) raises many questions. The answers to these questions will likely make important contributions to the entrepreneurship and hybrid organization literature.

\section{ENTREPRENEURSHIP AND THE DEGREE OF HYBRIDITY}

We seek to develop an agenda for future research by building on the revised conceptualization of the degree of hybridity and in taking an entrepreneurship perspective. To accomplish this, we explore the emergent processes of co-constructing opportunities as a unique and promising theoretical and empirical context for expanding theory on both hybrid organizing and entrepreneurship. We selected an entrepreneurship perspective as a promising pathway for the advancement of scholarship for three primary reasons.

First, the entrepreneur directly influences the degree of hybridity (Wry \& York, 2017) of an emerging organization and indirectly influences the degree of hybridity through the nature of the potential opportunity and the outcome of previous organizing efforts (Austin et al., 2006; Mair \& Marti, 2006; Short et al., 2009). We know from prior research that entrepreneurs can shape a new organization's core elements (e.g., logics, identity, form) (Hannan \& Freeman, 
1984) based on their motivation (Mueller, Wolfe, \& Syed, 2017), identity (Fauchart \& Gruber, 2011; Wry \& York, 2017), and attention to social problems and challenges (Moroz, Branzei, Parker, \& Gamble, 2018; Peredo, Haugh, \& McLean, 2017). As such, scholarship that examines the entrepreneur's impact on the emergence of organizations could provide key insights into the degree of hybridity by exploring the relativity and intensity of the hybridity.

Second, recent scholarship (Autio, Dahlander, \& Frederiksen 2013; Dentoni, Pascucci, Poldner, \& Gartner, 2017; Shepherd \& Williams, 2014; Williams \& Shepherd, 2016a, 2016b, 2018) has highlighted the important role of communities in interacting with entrepreneurs to generate and develop potential opportunities critical to the emergence of new organizations (Shepherd \& Williams, 2019). More specifically, scholarship has highlighted how communities of inquiry - collections of actors working toward a common objective - can influence the core logics of an organization during its emergence and evolution (Shepherd, 2015; Williams \& Shepherd, 2018). For example, Williams and Shepherd (2018) found that following a devastating bushfire, entrepreneurs created new ventures to help others with the aid of their networks of individuals. These networks functioned as communities of inquiry seeking to address suffering following the natural disaster. We anticipate that the community of inquiry directly shapes perceptions of a potential opportunity, which in turn influences the degree of hybridity for the emerging organization. Furthermore, we anticipate that interactions between communities of inquiry and entrepreneurs will shape both perceptions of opportunities and the degree of hybridity. Therefore, future research that explores the nature of causality between these important variables (and perhaps also the presence of mutual causation) will make an important contribution to the hybrid organizing literature. 
Finally, research on the co-construction of entrepreneurial opportunities that promise both economic and social value has garnered considerable interest from the broader management scholarly community (e.g., Alvarez, Woolley, \& Young 2015; Alvarez \& Barney, 2010; Davidsson, 2015, 2017; Dimov, 2007; Venkataraman, Sarasvathy, Dew, \& Forster, 2012; Wood \& McKinley, 2010). While there is a growing body of research on how entrepreneurs interact with communities of inquiry to co-construct opportunities (Autio, et al., 2013; Lyons et al., 2012; Pardales \& Girod, 2006), there is very limited scholarship examining how communityentrepreneur interactions shape hybridity (cf. Williams \& Shepherd, 2018). In our framework for future research, we highlight the benefits of including the potential opportunity as an area of focus as it links entrepreneurs (and their organizations) with communities of inquiry and is also likely to function as an antecedent to the degree of hybridity (and organizational outcomes).

In Figure 2, we sketch out an agenda as a first step toward explaining the degree of hybridity based on an entrepreneurship perspective - the emergence of organizations through the co-construction of potential opportunities. This model is consistent with calls for greater clarity in identifying the antecedents and outcomes of hybridity (Battilana et al., 2017). As proposed in Figure 2, we organize the agenda for future research around four central elements that shape organizational emergence - the entrepreneur, the community of inquiry, the nature of the social/economic potential opportunity, and organizational outcomes. This helps to structure our research agenda and offer a cohesive overview of how future research can fill the most pressing scholarly gaps. We now discuss each of the key elements in Figure 2 and identify possible topics to advance knowledge on hybridity in particular and entrepreneurship in general.

------INSERT FIGURE 2 ABOUT HERE------

Entrepreneurial Motivation, Potential Opportunities, and the Degree of Hybridity 
While entrepreneurship involves a number of important elements, a logical starting point is the entrepreneur and his/her motivation for pursuing a potential opportunity. To date, the bulk of entrepreneurship research has sought to explain factors that shape the emergence and success of organizations seeking to maximize financial returns (Austin, Stevenson, \& Wei-Skillern, 2006; Parker, 2018). Given this economic orientation, the focus of most individual-oriented entrepreneurship studies has been on the influence of entrepreneurs' self-interested motivation in shaping financial performance (Baum \& Locke, 2004; Shane, Locke \& Collins, 2003). In the next two sections, we briefly review the research on entrepreneurial motivation and affect, and given our interest in also considering the creation of social value, we devote particular attention to entrepreneur attributes that are highly salient to the social dimension of entrepreneurial action - namely, prosocial motivation and social-based affect. We conclude each section by offering specific recommendations for future research.

Motivation has a long history in entrepreneurship scholarship (e.g., Collins, Locke, \& Hanges, 2000; McClelland, 1961). Traditionally, this literature has focused on concepts like need for achievement, independence, comfort with ambiguity/uncertainty, and so forth (Low \& Macmillan, 1988; Venkataraman, 1997). Individual motivation is foundational to studies of entrepreneurship in that it explains (at least in part) how entrepreneurs persist in creating and pursuing opportunities (Collins et al., 2000; Shane et al., 2003). Building on this tradition, social entrepreneurship research (e.g., Conger, McMullen, Bergman, \& York, 2018) has highlighted the importance of an individual's prosocial motivation — or the desire to have a positive impact on other people or social collectives (Batson, 1987; Grant, 2007). This focus varies substantially from prior motivational scholarship, which generally assumed that entrepreneurial opportunities involve "potentialities for [economic] profit making" (Shane, Locke, \& Collins, 2012: 7). 
Therefore, there is likely much to be gained from a deeper understanding of how entrepreneurs' prosocial motivation influences (1) the co-construction of potential opportunities that create both economic and social gain and (2) the degree of hybridity of the organizations exploiting these potential opportunities.

Indeed, Miller et al. (2012) highlight that the motivations underlying social entrepreneurship (and associated outcomes for organizing) are undertheorized. Miller and colleagues (2012) argue that compassion, which serves as a prosocial motivation, leads to social innovation through the cognitive mechanisms of integrative thinking, prosocial cost-benefit analysis, and commitment to alleviating others' suffering. In a separate study, Renko (2013) finds that an individual's prosocial motivation shapes organizing processes and can enable progress in building a hybrid organization (see also McMullen \& Bergman, 2017). In summary, with greater prosocial motivation, an individual is more motivated to help out of concern for others (Batson, 1987), is more likely to feel good about him- or herself as he or she makes progress (Grant \& Berry, 2011), and is thus likely to invest more effort and other resources in exploiting subsequent potential opportunities for making prosocial progress.

Future research on emotion, potential opportunity, and hybridity. A focus on entrepreneurs' prosocial motivation, therefore, provides a basis for a number of important contributions to building knowledge on the degree of hybridity. First, combining the prosocial motivation literature (Batson, 1987; Grant, 2008) with theories of entrepreneurial action (McMullen \& Shepherd, 2006) allows for the exploration of novel research questions. For example, exploring how prosocial motivation combines with knowledge of social (or environmental) problems to generate third- and first-person opportunity beliefs (Patzelt \& Shepherd, 2011; Shepherd, 2015) may help explain difference in the relative importance of 
economic vis-a-vis social value creation. It could be that knowledge of a social problem leads to prosocial motivation, that prosocial motivation leads to knowledge of a social problem, or that prosocial motivation moderates (i.e., magnifies or dampens) the positive relationship between knowledge of a social problem and the social intensity of solving that problem. Indeed, future scholarship is needed to explore the nature and impact of prosocial motivation and opportunity co-construction on the degree of hybridity.

While it would appear (intuitively) that greater prosocial motivation combined with knowledge of social problems would lead to more intense hybridity, this remains to be tested. Similarly, those motivated to do good for others may not be the most effective at achieving positive social outcomes as good intentions can sometimes end up causing additional problems despite desires to help (Lupton, 2012; Schuller, 2012). Similarly, it is important to note that prosocial motivation does not preclude self-interest (Grant, 2008; Grant \& Berry, 2011), and thus we expect that the identification and pursuit of a potential opportunity to create greater social value does not necessarily come at the expense of lower economic value-that is, does not necessarily come at the expense of relative hybridity. We anticipate that future research can identify organizing and performance outcomes along the dimensions of the degree of hybridity highlighted in Figure 1c. For example, if exploiting potential opportunities of greater social value strengthens the social logic, thereby closing the gap between the strength of the economic and social logics, there will be an increase in both the intensity and relativity of hybridity. It could also be that the degree of hybridity changes with increased intensity but reduced relativity if the strength of the social logic continues to grow to the extent that the gap between it and the strength of the economic logic is widened. 
Second, a key concept of organizing involves mobilizing and interacting with other actors (e.g., employees, contractors, financers, etc.) to co-construct opportunities and achieve common objectives (Scott \& Davis, 2016; Weick, 1979). Therefore, it is important to know how an entrepreneur's prosocial motivation influences his or her employees' prosocial motivation, behavior, and impact. Under certain conditions, the entrepreneur's prosocial motivation might become a collective prosocial motivation reflected in the hiring process, the organizational culture, and/or routines and systems that direct employees' attention, effort, and commitment toward helping others outside the organization (Perlow \& Weeks, 2002; Van Dyne \& LePine, 1998). The more the entrepreneur's prosocial motivation becomes a collective motivation, the stronger the organization's social logic. This social logic could be manifest either through formal organizational changes (i.e., mission statements, hierarchy, marketing, etc.) that align with the entrepreneur's motivation or through informal actions that may or may not vary from original organizing principals and activities. Because we propose that strengthening the social logic does not necessarily weaken the economic logic (based on the notion that prosocial motivation does not preclude self-interest [Grant, 2008; Grant \& Berry, 2011]), to determine an organization's degree of hybridity, the intensity of the economic logic and the relative emphasis of the social logic vis-à-vis the economic logic also need to be captured.

Similarly, as members of the community of inquiry are co-constructing potential opportunities with entrepreneurs, it is also important to assess whether and how key stakeholders' (e.g., early employees, mentors, etc.) prosocial motivations shape the entrepreneur's motivations and actions. While co-constructing opportunities, external audiences are likely to provide feedback, input, and other perspectives that can shape the direction and motivation of the organization (Wood \& McKinley, 2010). Indeed, there could be conflicting 
motivations among various actors that differentially shape the relativity and intensity of the organization's hybridity.

Finally, motivation to help someone does not always mean that the person will be helped (Lupton, 2012). Despite this fact, much of the extant scholarship (cf. Williams \& Shepherd, 2018) on social venturing has failed to directly measure ventures' social impact (i.e., social performance); rather, this work has explored the impact of social venturing on traditional economic outcomes for the helping organization (Godfrey, 2005; Godfrey, Merrill, \& Hansen, 2009). In acknowledging this gap, Grant and Berg (2010: 26) call for more research on the "dark side" of prosocial motivation, arguing that it is "the most important new direction for inquiry" to better understand when and how prosocial motivation fuels unethical behavior or harm doing such that good intentions to "help" end up undermining those being served (e.g., Lupton, 2012; Schuller, 2012; Williams \& Shepherd, 2016a). Perhaps it is the high intensity of the economic logic and/or the social logic that leads to the "dark side." But the dark side may manifest itself differently for an unbalanced organization with high economic intensity, for a balanced organization with high economic and social intensity, and for an unbalanced organization with high social intensity. We hope future research explores these differences.

It could also be that prosocial motivation does not lead to action or leads to ineffective action, such as helping people in a way they do not want or need and thus exacerbating the problem. Ineffective action—regardless of how well intentioned-may damage "the cause" by, for example, wasting donor resources on an ineffective attempt to help others. Indeed, it is important for future research to consider the combination of prosocial motivation with different types of opportunity-related knowledge, such as knowledge about those experiencing the social problem; knowledge related to creating a solution to the social problem; and knowledge of 
markets, technologies, and organization building. It is the combination-or perhaps configuration — of different motives and different types of opportunity-based knowledge that will not only help explain the generation of potential opportunities that create both economic and social value but also influences the degree of hybridity in organizing the exploitation of such opportunities. Based on the above reasoning, we offer the following research question to hopefully stimulate further theoretical and empirical research:

Research Question 1: What impact does the entrepreneur's prosocial motivation have on the emerging organization's degree of hybridity? Specifically, how, when, and why does the entrepreneur's prosocial motivation impact (a) the relative importance gap between the organization's economic and social logics and (b) the intensity of the organization's economic and social logics?

\section{Entrepreneurs' Affect, Potential Opportunities, and the Degree of Hybridity}

Affect refers to an individual's feelings, emotions, and moods (Foo, 2011; Goss, 2005) and plays a key role in the entrepreneurial process by shaping individuals' identification of potential opportunities, influencing resource acquisition for the creation of new ventures, and impacting firm performance (Baron, 2008; Foo, Uy, \& Baron, 2009; Cardon et al., 2012). As it relates to social entrepreneurship, scholars have identified links between an actor's ability to connect emotionally with those in need and that actor's social entrepreneurship intentions (Bacq \& Alt, 2018; Dees, 2012; Miller et al., 2012). Recent research has shown that organizations' capacity for compassion (Kanov et al., 2004) is an important factor in shaping processes to identify opportunities for the creation of hybrid organizations (Miller et al., 2012; Shepherd \& Williams, 2014; Williams \& Shepherd, 2018). Compassion involves the ability to notice, feel concern for, and respond to (i.e., behave with the intention to alleviate) another's suffering 
(Dutton et al., 2006; Kanov et al., 2004). Noticing and, in particular, feeling empathic concern toward others is inherently an affective concept and presents clear linkages to prominent themes in hybrid organizing (e.g., Wry \& York, 2017). Therefore, it is surprising that the impact of empathy-related affect has not played a more prominent role in studies of hybrid organizingsurprising because recognizing a social problem and its corresponding suffering is likely to stimulate emotions in those initiating and involved in hybrid organizing. For example, the extent of suffering from a social problem (and who is suffering) is likely to generate specific emotions in the entrepreneur that in turn impact the co-construction of potential opportunities to create economic and social value. Indeed, affective responses to others' suffering (Williams et al., 2017) could impact the entrepreneurial process and its outcomes in a number of ways.

Future research on affect, potential opportunities and hybridity. We anticipate that differences in individuals' affective attentiveness to social problems can lead to heterogeneity in the degree and impact of hybrid organizing efforts. Perhaps the widespread suffering from a social problem generates a negative emotional reaction that draws a potential entrepreneur's attention to the problem, and given a desire to reduce these negative emotions, the entrepreneur is motivated to identify and develop a solution (e.g., the entrepreneur increases the intensity of the social logic). Indeed, social problems that produce little emotional reaction in individuals are unlikely to capture the attention and generate the effort necessary to diagnose and formulate solutions.

Alternatively, a severe negative emotional reaction may motivate the entrepreneur to avoid thinking about the social problem (as a means of coping) (Davis, 1983) - that is, reduce the relative importance of the social logic vis-à-vis the economic logic- - which in turn may reduce his or her cognitive capacity to generate a creative solution to the problem (for the 
negative impact of negative emotions on the cognitions involved in problem solving, see Fredrickson [1998]). Alternatively, an extreme negative emotional reaction to suffering (i.e., horror, deep sadness) could result in action that, while well intentioned, does not directly solve the problem (Williams \& Shepherd, 2016a) or even makes it worse by creating "toxic dependencies" (Schuller, 2012).

As an organization emerges and progresses, the entrepreneur is likely to experience positive emotions, which in turn facilitate the cognitive functioning (Fredrickson, 1998) that is useful in performing entrepreneurial tasks. These positive emotions likely help balance the intense negative emotions individuals experience when exposed to human suffering or trauma. Therefore, more research is needed to explore how the emotions (positive and negative) generated from noticing, feeling, and responding to others' suffering directly influence the degree of hybridity and indirectly influence the degree of hybridity through the co-construction of potential opportunities. To guide this important research, we offer the following research question:

Research Question 2: What impact does the entrepreneur's affect (negative and positive) have on the emerging organization's degree of hybridity? Specifically, how, when, and why does the entrepreneur's different affect impact (a) the relative importance gap between the organization's economic and social logics and (b) the intensity of the organization's economic and social logics?

Finally, the logics of hybrid organizing sometimes compete, creating conflict (Jay, 2013; Pache \& Santos, 2013) that can then trigger negative emotional reactions (e.g., Pelled, Eisenhardt, \& Xin, 1999). We propose that the greater the degree-relativity and intensity_of hybridity (i.e., a strong social logic and a strong economic logic), the more likely conflict will 
arise among organizational members. Perhaps entrepreneurs who can best manage a high degree of hybridity are those high in emotional intelligence. Indeed, highly emotional individuals are likely to notice, understand, and regulate the emotional aspects of conflict (Jordan \& Troth, 2004; Schlaerth, Ensari, \& Christian, 2013) arising from hybridity. Alternatively, or perhaps in conjunction, emotionally intelligent entrepreneurs may be better at understanding the emotions of their organization's members (and perhaps also members of communities of inquiry for potential opportunities), leading them to choose a degree of hybridity that provides a "doable" level of conflict for the members or the emotionally intelligent entrepreneurs can help members "cope with" the greater emotional conflict arising from a high degree of hybridity. Based on the above reasoning, we offer the following research question:

Research Question 3: What impact does the organization's degree of hybridity have on the generation of conflict-based emotions? Specifically, are conflict-based emotions generated by (a) a reduction in the relative importance gap between the organization's economic and social logics and/or (b) an increase in the intensity of one logic that is not offset by a decrease in the intensity of the other logic?

\section{Communities of Inquiry, Potential Opportunities, and the Degree of Hybridity}

Another important element of organizational emergence is the involvement of other stakeholders, or a community of inquiry. While entrepreneurs clearly play a significant role in shaping the identities, actions, and strategies of new organizations (Besherov, 2014; Smith \& Besherov, 2018; Wry \& York, 2017), these organizations are also shaped by other actors and stakeholders in fundamental ways. Indeed, social entrepreneurship often involves broader communities who share a mutual interest in the development and exploitation of a potential opportunity (Peredo \& Chrisman, 2006; Short, Moss \& Lumpkin, 2009). In this way, 
entrepreneurs can innovate in collaboration with broader communities to identify and pursue opportunities (Autio et al., 2013; Pardales \& Girod, 2006; Shepherd, 2015). It is likely that these interactions will result in the evolution of organizations' hybridity given the input of these various and often diverse stakeholders, especially during the co-construction of potential opportunities that create both high economic and high social value. Organizing to exploit such potential opportunities (high economic and high social value) will likely require a high degree of hybridity - that is, a strong economic logic and a strong social logic. Therefore, we need to gain a deeper understanding of how potential opportunities with both high economic and high social potential value are refined as they "move between" entrepreneurs and communities of inquiry.

The interactions between the entrepreneur and the community of inquiry are likely nonlinear and highly inter-dependent, reflecting the evolution of the community of inquiry, the entrepreneur's opportunity beliefs, the nature of the potential opportunity, and thus, the emergent organization. For example, recent trends in community-based resourcing, such as micro-lending and crowdfunding (e.g., kiva.org [Flannery, 2007]) (Einav, Farronato, \& Levin, 2016; Moss, Renko, Block, \& Meyskens, 2018; Zervas, Proserpio, \& Byers, 2016), shift the resource provider-seeker relationship and present new roles for communities of inquiry in opportunity development and pursuit. Importantly, technology has allowed communities of inquiry to collaborate beyond merely providing resources in that they can function as active co-constructors of potential opportunities (Fisher, 2018). This co-construction process is likely more critical when the potential opportunity is to create high value in both the economic and social forms of wealth. Furthermore, due to the potentially evolving nature of communities of inquiry over time and the ongoing adjustments entrepreneurs make to their missions and visions in response to those communities (Einav et al., 2016), there are likely to be frequent conflicts between 
entrepreneurs and communities in identifying the "target impact" of the organization (i.e., degree of hybridity).

Future research on communities of inquiry, potential opportunities, and hybridity. As we gain a deeper understanding of the mutual adjustment process involved in refining potential opportunities to solve social problems in economically advantageous ways, we are likely to gain insights into the origin and dynamism of the degree of hybridity in organizing the exploitation of potential opportunities to create both economic and social wealth. For example, when an entrepreneur receives feedback on a potential opportunity, he or she is likely to refine that opportunity, which can in turn lead to changes in the composition of the community of inquiry (Shepherd, 2015). Changes to the community of inquiry can lead to additional changes to the nature of the potential opportunity (e.g., perhaps greater emphasis on the creation of a particular source of social value or an emphasis on economic value or both) such that there is a strengthening or weakening of the economic logic and a strengthening or weakening of the social logic of the organization. These changes in the strength of logics will change both the relativity and intensity (i.e., the overall degree) of the organization's hybridity.

Just as the entrepreneur is likely to experience affect and this affect is intertwined with the refinement of a potential opportunity to create both economic and social value, the community of inquiry is likely to experience emotions (varied in valence and intensity) that influence community members' beliefs, actions, and interactions with the entrepreneur during the co-construction of a potential opportunity. The results of these interactions, emotions, and exchanges between the community of inquiry and the entrepreneur can influence the entrepreneur's emotions and shape the organization's degree of hybridity. For example, if people continue to suffer after the entrepreneur's attempts to solve the underlying social problem, that 
suffering may (re)trigger negative emotions in the entrepreneur, signaling insufficient progress and the need to make a change in the organization's hybridity to strengthen the social logic. The reverse could be the case as well: the economic value generated by the venture could trigger positive emotions (from increased personal economic wealth) that outweigh the negative emotions (or undo the negative emotions [Fredrickson, 1998]) caused by an inadequate social solution, thus encouraging a shift in the degree of hybridity toward a stronger economic logic. Again, there is a need to investigate the affect of the community of inquiry, the influence of the community of inquiry on the entrepreneur's affect, and the impact of both on the degree of hybridity. Based on the above reasoning, we offer the following research question:

Research Question 4: What impact does the community of inquiry have on the organization's degree of hybridity? Specifically, how, when, and why does the community of inquiry impact (a) the relative importance gap between the organization's economic and social logics and (b) the intensity of the organization's economic and social logics?

Research Question 5: How, when, and why does (a) a decrease in the relative importance gap between the organization's economic and social logics and (b) an increase in the intensity of the organization's economic and social logics impact the nature and composition of the community of inquiry?

\section{Successful Organizational Outcomes and the Degree of Hybridity}

While entrepreneurship and strategic management scholarship has extensively explored factors that shape the economic performance of business ventures (Parker, 2018), research exploring ventures' social performance is still emerging. Indeed, scholars seek to identify both the nature of social outcomes and indicators of high performance within those outcomes. 
Possible social outcomes include, for example, subjective satisfaction (Kroeger \& Weber, 2014); societal progress (Gundry et al., 2011); enhanced human experience (Zahra \& Wright, 2016); the preservation of cultural and natural environments (Peredo \& Chrisman, 2006); the alleviation of suffering after disasters (Dutta, 2017; Williams \& Shepherd, 2016b, 2018); reduced poverty (Peredo \& Chrisman, 2006); crowdfunding success (Parhankangas \& Renko, 2017; Josefy et al., 2016; Calic \& Mossakowski, 2016); food, water, shelter, and education (Certo \& Miller, 2008); microloan organizations' performance (Wry \& Zhao, 2018; Zhao \& Lounsbury, 2016); “faith, hope, comfort and salvation" (Pearce et al., 2010); the empowerment of women (Datta \& Gailey, 2012; Zhao \& Wry, 2016); and both poverty reduction and conflict resolution in Rwanda's entrepreneurial coffee sector (Tobias et al., 2013). In contrast to these specific descriptions of social outcomes, other studies (typically conceptual papers) have been broader in their descriptions of social outcomes—for example, social value (e.g., Di Domenico et al., 2010)—or even broader across both the economic and the social in the form of blended value (e.g., McMullen \& Warnick, 2016), total value (e.g., Zahra et al., 2009), and the triple bottom line (Mair, et al., 2006).

As scholars explore various social problems, they uncover different mechanisms for assessing performance. For example, at the individual level of analysis, Bolino and Grant (2016: 62) offer the notion of prosocial impact- "the experience of making a positive difference in the lives of others ... through one's work"-which highlights the impact of successful prosocial actions on those needing help. Similarly, Williams and Shepherd (2018) measure the impact of compassionate venturing efforts by assessing the speed, magnitude, and customization of responses to address the needs of those suffering from a natural disaster. Prosocial impact, in the focal context, is based on the entrepreneur's recognition and evaluation of the impact of his or 
her organization on others. This recognition of impact may represent the proverbial "patting oneself on the back," which itself may have important implications for ongoing and subsequent venturing.

Future research on degrees of hybridity and organizational outcomes. While the body of hybrid organizing scholarship is growing, question of how the entrepreneur assesses the impact of his or her organization remains. The entrepreneur may assess the value created by his or her organization in line with his or her original goals for the combination of economic and social wealth created. In contrast, perhaps the entrepreneur's goals for the combination of economic and social wealth are determined by his or her assessment of the organization's current performance - in this case, through a post hoc establishment of the degree of hybridity in organizing. Furthermore, successful outcomes may change the organization's logics. For example, having achieved success, the entrepreneur might feel freer to organize his or her organization to emphasize more of the social aspects of the value created (consistent with a resource slack argument), thus representing a strengthening social logic. Alternatively, success may lead to organizing that is more risk averse in the pursuit of social value (consistent with prospect theory), thus representing a weakening social logic. We suspect that success in creating social value can be highly intrinsically rewarding for the entrepreneur (and perhaps more so than initially anticipated) and may thus strengthen the social logic of the organization (without necessarily weakening the economic logic), which in turn increases the intensity of hybridity.

"Success" for an organization could mean (1) "We've solved the problem. Let's close down the venture"; (2) "We've solved the problem here. Let's solve it there"; (3) "We've solved this problem. Now, let's solve that problem"; or (4) "We've solved the problem to some degree. Now, let's solve it at a greater scale." These steps after success are very different from the "Let's 
just make a profit" success goal and may be the source of a "dark side" to achieving success in social ventures. For example, if an organization eradicates its targeted social problem through effective organizing, it has essentially displaced its "use case." Could this realization lead to unnecessary persistence in a social endeavor when business cessation would be more appropriate? As suggested earlier, helping others can generate positive emotions, pushing individuals to continue on. However, this push to continue could undermine the necessary process of disintervention-disengaging to provide those who were "helped" the autonomy to help themselves (Nili, 2011). This area of organizing research could potentially serve as a parallel argument to those made in the traditional economic literature on the potential "perils of excellence" (Miller, 1994). For example, future studies could explore different types of performance (e.g., dissolving a venture due to accomplished goals, serving the maximum number of people, enabling independence in those being helped, moving from one social problem to another, etc.) and the ways different forms of organizing shape performance.

Furthermore, we know that the community of inquiry can influence the entrepreneur's opportunity beliefs and the refinement of a potential opportunity (Autio et al., 2013; Shepherd, 2015). Thus, the entrepreneur's assessment of prosocial impact is likely influenced by the community of inquiry's beliefs about, actions toward, and reactions to the outcomes of the current hybrid organizing (i.e., the apparent degree of hybridity). Thus, a disconnect between the entrepreneur's and the community of inquiry's assessments of the organization's impact likely leads to a change in beliefs and, subsequently, a change in the nature of the potential opportunity co-constructed and the degree of hybridity. Indeed, prosocial impact can be considered "interim" feedback about the potential opportunity to the entrepreneur from the community of inquiry; 
therefore, the community of inquiry can influence the strength of the organization's logics and thus the degree of hybridity. Based on the above reasoning, we offer the following:

Research Question 6: What impact does the successful exploitation of a potential opportunity to create economic and social value have on the organization's degree of hybridity? Specifically, how, when, and why does the successful exploitation of a potential opportunity to create economic and social value impact (a) the relative importance gap between the organization's economic and social logics and (b) the intensity of the organization's economic and social logics?

Research Question 7: How, when, and why does (a) a decrease in the relative importance gap between the organization's economic and social logics and (b) an increase in the intensity of the organization's economic and social logics impact the likelihood of successfully exploiting a potential opportunity to create economic and social value?

\section{Failure as an Organizational Outcome and the Degree of Hybridity}

The pursuit of potential opportunities inherently involves navigating uncertainty (Knight, 1921; McGrath, 1999). As such, a great number of entrepreneurial endeavors end in failure (Headd, 2003; Wiklund, Baker, \& Shepherd, 2010). A significant body of research has explored failure (Shepherd, Williams, Patzelt, \& Wolfe, 2016; Ucbasaran et al., 2013), including the challenges (e.g., grief, loss, and disruption for the entrepreneur [Cope, 2011; Shepherd, 2003]) and benefits (e.g., learning and renewal [Hoetker \& Agarwal, 2007; Knott \& Posen, 2005; Shepherd, 2003]) of failure. Indeed, we also have a good understanding of individuals' reluctance to terminate failing ventures (DeTienne, et al., 2008; Shepherd, Wiklund, \& Haynie, 2009) as well as of the financial (Lee, Yamakawa, Peng, \& Barney, 2011), emotional (Shepherd, 
2003), and social (Cardon, Stevens, \& Potter, 2011) consequences arising from the failure of economically driven organizations (for a review, see Ucsbasaran et al., 2013).

Future research on degree of hybridity and failure. While entrepreneurship scholarship has advanced our understanding of the costs and outcomes of traditional business failure, there is much to be learned about the antecedents and outcomes of hybrid venture failure. Indeed, there are likely important differences in the consequences of an organization's failure for those involved (i.e., the entrepreneurs and members of the community of inquiry) depending on the degree of hybridity. Specifically, the assessment of what represents unacceptable performance and the need for termination (i.e., the performance threshold under which a venture is terminated [Gimeno, Folta, Cooper, \& Woo, 1997]) is more complex when considering both economic and social performance together than when considering one type of performance or the other. As we argued above, there are numerous ways to assess organizational performance from a hybridity perspective, which suggests the need for different criteria to evaluate performance. Without a nuanced understanding of the dimensions of performance (and how they are weighted and combined across individuals), it is difficult to determine when an organization is failing - that is, it is difficult for the entrepreneur to know when it is time to change the degree of hybridity, persist, or terminate the organization entirely.

Therefore, it is important for us to build new knowledge about how emphasis on poor economic performance and poor social performance and the interaction of the two influence entrepreneurs' termination decision policies and the broader consequences of the termination of organizations based on their degree of hybridity. Could persisting with an organization despite it having achieved its mission or having failed to address the social ill end up altering motivations? For example, an organization might alleviate suffering and "put itself" out of business by 
eliminating the need for its services or products. However, due to the power attained by dominating a market, the organization might persist. Similarly, an organization might aggressively compete with others to address a social ill, expending resources and energy on "winning the social market" rather than simply allowing the solution that best eliminates the social problem to achieve its objectives.

Perhaps organizations with a strong social logic and a weak economic logic (i.e., lowhybridity social ventures) are more likely to escalate commitment to losing courses of action in response to both anticipating the loss of social benefits to those in need from organizational failure and anticipating stronger feelings of shame, disappointment, and other negative emotions vis-à-vis organizations with a weaker social logic and/or a stronger economic logic. ${ }^{2}$ Specifically, perhaps entrepreneurs' level of grief over the failure of an organization is higher (and both learning and recovery are slower) for organizations with a stronger social logic. That is, perhaps entrepreneurs' negative emotional reactions to the loss of such organizations are greater because the associated social problems persist (e.g., people who could have otherwise been helped if the organization had not failed continue to suffer).

However, grief is a negative emotional reaction to the loss of something important (Archer, 1999). A strong logic, whether economic or social, indicates the high importance assigned to creating economic and social value, respectively. Therefore, perhaps there are no substantial differences in the level of grief over the loss of an organization with a strong economic logic versus a venture with a strong social logic. Indeed, entrepreneurs (and members)

\footnotetext{
2 Escalation of commitment can lead to permanently failing organizations that create an economic drain on society (McGrath, 1999; Meyer and Zucker, 1989). Permanently failing hybrid ventures are likely a subset of all permanently failing organizations. What is the economic and social drain on a society from permanently failing organizations at different degrees of hybridity?
} 
of organizations with a high degree of hybridity — a strong economic logic and a strong social logic - are likely to experience the most grief because they lose something of high importance on multiple fronts. Future research can explore entrepreneurs' negative emotional reactions to their organizations' failure and the moderating role of the degree of hybridity in this relationship. Understanding the level of grief is important because it helps explain learning from failure and the motivation to try again (Shepherd, 2003, 2009).

Further, organizations are not always voluntarily terminated; sometimes resource providers "pull the plug." It is important to understand how investors decide to pull the plug on organizations based on their degree of hybridity and the nature of the community of inquiry. Whether the plug is pulled by the entrepreneur or an investor, we know that entrepreneurs are typically stigmatized for their failure (Cardon, et al., 2011), but this stigma has been found to be less for entrepreneurs who tried to create non-economic value (e.g., protect the natural environment [Shepherd \& Patzelt, 2015]). Perhaps entrepreneurs of failed social ventures are less stigmatized by the public than those of purely economic ventures, but does the level of stigmatization depend on the degree of hybridity, the type of social problem, or the geographic location?

Despite grief over organizational failure, entrepreneurs have an opportunity to learn from their failure experience and try again by creating a subsequent organization (Bau et al., 2017; Hsu et al., 2017; Shepherd et al., 2014). Therefore, it is important to understand how the degree of hybridity of failed organizations influences entrepreneurs' ability to learn from failure and their motivation to try again and how failure experiences affect the degree of hybridity in subsequent entrepreneurial pursuits. If entrepreneurs try again after the failure of their organizations, what do they learn about the degree of hybridity? For example, does the 
entrepreneur deliberately create a new organization with a different degree of hybridity than the previous organization, does the entrepreneur implement a different set of mechanisms to better manage the tradeoff (and exploit complementarities) between the economic and social logics, and/or does the entrepreneur identify and co-construct (with a different community of inquiry) a potential opportunity with a different mix of economic and social value? Addressing these questions can advance our knowledge of entrepreneurship and will hopefully have practical implications for the formation and management of organizations with differing degrees of hybridity. Based on the above, we offer the following:

Research Question 8: What impact does the failure of an organization (with a given degree of hybridity) have on the degree of hybridity of the entrepreneur's next organization? Specifically, how, when, and why does organizational failure impact (a) the relative importance gap between the subsequent organization's economic and social logics and (b) the intensity of the subsequent organization's economic and social logics?

Research Question 9: How, when, and why does (a) a decrease in the relative importance gap between the organization's economic and social logics and (b) an increase in the intensity of the organization's economic and social logics impact the likelihood of the organization failing?

\section{CONCLUSION}

The purpose of the current paper was to offer a revised conceptualization of the degree of hybridity to provide a framework organized around key processes of entrepreneurship that encourages further exploration of the antecedents and consequences of hybrid organizing. Beyond the specific research opportunities detailed above, we offer three more general recommendations about conducting such research. First, to understand how actors combine and 
blend dimensions of hybridity—namely, relative hybridity and hybrid intensity—we likely need to combine and blend different literatures for our theorizing. In other words, to develop new individual- and cross-level theories of hybrid organizing, it will not be sufficient to borrow theories from other disciplines (e.g., psychology) but will require conceptual blending (Oswick et al., 2011) - that is, theory building through an analogous process (Weick, 1989) that involves a two-way exchange between the source theory (e.g., from a discipline like psychology) and the target (e.g., the degree of hybridity). This two-way exchange provides the opportunity to create new theories of hybrid organizing (including a counterintuitive blend) as well as contributions back to the source theory.

Second, while scholars can continue to investigate hybridity in old and established organizations, there are many interesting research questions around the formation and emergence of new organizations. The "pre" of the pre-organization and the "newness" of the new organization are both challenging topics for research on hybridity but are rewarding for those willing and capable of taking on the challenge. Although interesting in their own right, hybridity research focused on the pre and the new of organizing provides the basis for understanding antecedents to the large and growing literature on well-established hybrid organizations. A focus on the pre and the new highlights the importance of investigating potential opportunities to create both economic and social value, which are likely more complex, more subjective, and more coconstructed than potential opportunities to create economic value. Thus, in studying the degree of hybridity in organizing specifically and entrepreneurship more generally, we will gain much new knowledge from keeping our eyes on entrepreneurs and their potential and evolving opportunities to create economic and social value. 
Finally, scholars are always told to choose a topic they are passionate about, but this general advice is difficult to translate into specifics. Research on the hybridity organizing is not tied to a single dependent variable, and scholars have the opportunity to explore social and/or environmental problems that are close to their heart, identity, and/or office. For example, a scholar who lifted him- or herself up by the bootstraps may be motivated and have "inside information" useful for investigating entrepreneurs' motivation to alleviate poverty. The hybridity of organizing is a research topic rich in various outcomes, and scholars have the unique chance to put themselves in the shoes of actors who are making a difference in the world (and hopefully, in doing so, we can make a difference in the world—an ambitious but worthwhile notion of our research potential). 


\section{REFERENCES}

Alvarez, S. A., \& Barney, J. B. (2010). Entrepreneurship and epistemology: The philosophical underpinnings of the study of entrepreneurial opportunities. Academy of Management annals, 4(1), 557-583.

Alvarez, S. A., Young, S. L., \& Woolley, J. L. (2015). Opportunities and institutions: A cocreation story of the king crab industry. Journal of Business Venturing, 30(1), 95-112.

Archer, J. (2003). The nature of grief: The evolution and psychology of reactions to loss. London: Routledge.

Austin, J., Stevenson, H., \& Wei-Skillern, J. (2006). Social and commercial entrepreneurship: Same, different, or both? Entrepreneurship Theory and Practice, 30(1), 1-22.

Autio, E., Dahlander, L., \& Frederiksen, L. (2013). Information exposure, opportunity evaluation, and entrepreneurial action: An investigation of an online user community. Academy of Management Journal, 56(5), 1348-1371.

Bacq, S., \& Alt, E. (2018). Feeling capable and valued: A prosocial perspective on the link between empathy and social entrepreneurial intentions. Journal of Business Venturing, 33(3), 333-350.

Baron, R. A. (2008). The role of affect in the entrepreneurial process. Academy of Management Review, 33(2), 328-340.

Batson, C. D. (1987). Prosocial motivation: Is it ever truly altruistic?. Advances in Experimental Social Psychology, 20, 65-122. 
Battilana, J., \& Dorado, S. (2010). Building sustainable hybrid organizations: The case of commercial microfinance organizations. Academy of Management Journal, 53(6), 14191440.

Battilana, J., \& Lee, M. (2014). Advancing research on hybrid organizing-Insights from the study of social enterprises. Academy of Management Annals, 8(1), 397-441.

Battilana, J., M. Sengul, A.-C. Pache, J. Model. (2015). Harnessing productive tensions in hybrid organizations: The case of work integration social enterprises. Academy of Management Journal, 58(6) 1658-1685.

Battilana, J., Besharov, M., \& Mitzinneck, B. (2017). On hybrids and hybrid organizing: A review and roadmap for future research. Sage handbook of organizational institutionalism, 2, 133-169.

Baù, M., Sieger, P., Eddleston, K. A., \& Chirico, F. (2017). Fail but Try Again? The Effects of Age, Gender, and Multiple-Owner Experience on Failed Entrepreneurs' Reentry. Entrepreneurship Theory and Practice, 41(6), 909-941.

Baum, J. R., \& Locke, E. A. (2004). The relationship of entrepreneurial traits, skill, and motivation to subsequent venture growth. Journal of Applied Psychology, 89(4), 587.

Ben-Ner, A. (2002). The shifting boundaries of the mixed economy and the future of the nonprofit sector. Annals of Public and Cooperative Economics, 73(1), 5-40.

Besharov, M. L. (2014). The relational ecology of identification: How organizational identification emerges when individuals hold divergent values. Academy of Management Journal, 57(5), 1485-1512. 
Bolino, M. C., \& Grant, A. M. (2016). The bright side of being prosocial at work, and the dark side, too: a review and agenda for research on other-oriented motives, behavior, and impact in organizations. Academy of Management Annals, 10(1), 599-670.

Calic, G., \& Mosakowski, E. (2016). Kicking off social entrepreneurship: how a sustainability orientation influences crowdfunding success. Journal of Management Studies, 53(5), 738-767.

Cardon, M. S., Foo, M. D., Shepherd, D., \& Wiklund, J. (2012). Exploring the heart: Entrepreneurial emotion is a hot topic. Entrepreneurship Theory and Practice, 36(1), 110.

Cardon, M. S., Stevens, C. E., \& Potter, D. R. (2011). Misfortunes or mistakes?: Cultural sensemaking of entrepreneurial failure. Journal of Business Venturing, 26(1), 79-92.

Certo, S. T., \& Miller, T. (2008). Social entrepreneurship: Key issues and concepts. Business Horizons, 51(4), 267-271.

Chhabra. (2018). https://www.forbes.com/sites/eshachhabra/2018/08/08/this-kenyan-femalefounder-wants-to-radically-change-the-coffee-industry/\#58d4a1981cac

Cobb, J. A., Wry, T., \& Zhao, E. Y. (2016). Funding financial inclusion: Institutional logics and the contextual contingency of funding for microfinance organizations. Academy of Management Journal, 59(6), 2103-2131..

Collins, C., Locke, E., \& Hanges, P. (2000). The relationship of need for achievement to entrepreneurial behaviour: a meta-analysis. Working paper, University of Maryland, College Park, MD. 
Conger, M., McMullen, J. S., Bergman Jr, B. J., \& York, J. G. (2018). Category membership, identity control, and the reevaluation of prosocial opportunities. Journal of Business Venturing, 33(2), 179-206.

Cope, J. (2011). Entrepreneurial learning from failure: An interpretative phenomenological analysis. Journal of Business Venturing, 26(6), 604-623.

Dacin, M. T., Dacin, P. A., \& Tracey, P. (2011). Social entrepreneurship: A critique and future directions. Organization Science, 22(5), 1203-1213.

Datta, P. B., \& Gailey, R. (2012). Empowering women through social entrepreneurship: Case study of a women's cooperative in India. Entrepreneurship Theory and Practice, 36(3), $569-587$.

Davidsson, P. (2015). Entrepreneurial opportunities and the entrepreneurship nexus: A reconceptualization. Journal of Business Venturing, 30(5), 674-695.

Davis, M.H. (1983). Measuring individual differences in empathy: evidence for a multidimensional approach. Journal of Personality and Social Psychology, 44, 113126.

Dees, J. G. (2012). A tale of two cultures: Charity, problem solving, and the future of social entrepreneurship. Journal of Business Ethics, 111(3), 321-334.

Dentoni, D., Pascucci, S., Poldner, K., \& Gartner, W. B. (2018). Learning "who we are” by doing: Processes of co-constructing prosocial identities in community-based enterprises. Journal of Business Venturing, 33(5), 603-622.

DeTienne, D. R., Shepherd, D. A., \& De Castro, J. O. (2008). The fallacy of "only the strong survive": The effects of extrinsic motivation on the persistence decisions for underperforming firms. Journal of Business Venturing, 23(5), 528-546. 
Di Domenico, M., Haugh, H., \& Tracey, P. (2010). Social bricolage: Theorizing social value creation in social enterprises. Entrepreneurship Theory and Practice, 34(4), 681-703.

Dimov, D. (2007). From opportunity insight to opportunity intention: The importance of person-situation learning match. Entrepreneurship Theory and Practice, 31(4), 561-583.

Dutta, S. (2017). Creating in the Crucibles of Nature's Fury: Associational Diversity and Local Social Entrepreneurship after Natural Disasters in California, 1991-2010. Administrative Science Quarterly, 62(3), 443-483.

Dutton, J. E., Worline, M. C., Frost, P. J., \& Lilius, J. (2006). Explaining compassion organizing. Administrative Science Quarterly, 51(1), 59-96.

Ebrahim, A., Battilana, J., \& Mair, J. (2014). The governance of social enterprises: Mission drift and accountability challenges in hybrid organizations. Research in Organizational Behavior, 34, 81-100.

Einav, L., Farronato, C., \& Levin, J. (2016). Peer-to-peer markets. Annual Review of Economics, 8, 615-635.

Fauchart, E., \& Gruber, M. (2011). Darwinians, communitarians, and missionaries: The role of founder identity in entrepreneurship. Academy of Management Journal, 54(5), 935-957.

Fisher, G. (2018). Online communities and firm advantages. Academy of Management Review, In press.

Fiol, C. M., Pratt, M. G., \& O'Connor, E. J. (2009). Managing intractable identity conflicts. Academy of Management Review, 34(1), 32-55.

Flannery, M. (2007). Kiva and the birth of person-to-person microfinance. Innovations: Technology, Governance, Globalization, 2(1-2), 31-56. 
Fonville. (2018). https://www.mdjonline.com/neighbor newspapers/dekalb/business/newlyopened-supreme-burger-in-decatur-aims-to-satisfy-community/article_0bcdd06a-aa1611e8-956b-0b7726b16f4e.html.

Foo, M. D. (2011). Emotions and entrepreneurial opportunity evaluation. Entrepreneurship Theory and Practice, 35(2), 375-393.

Foo, M. D., Uy, M. A., \& Baron, R. A. (2009). How do feelings influence effort? An empirical study of entrepreneurs' affect and venture effort. Journal of Applied Psychology, 94(4), 1086.

Fosfuri, A., Giarratana, M. S., \& Roca, E. (2016). Social Business Hybrids: Demand Externalities, Competitive Advantage, and Growth Through Diversification. Organization Science, 27(5), 1275-1289.

Fredrickson, B. L. (1998). What good are positive emotions?. Review of General Psychology, 2(3), 300-319.

Gimeno, J., Folta, T. B., Cooper, A. C., \& Woo, C. Y. (1997). Survival of the fittest? Entrepreneurial human capital and the persistence of underperforming firms. Administrative Science Quarterly, 750-783.

Godfrey, P. C. (2005). The relationship between corporate philanthropy and shareholder wealth: A risk management perspective. Academy of Management Review, 30, 777-798.

Godfrey, P. C., Merrill, C. B., \& Hansen, J. M. (2009). The relationship between corporate social responsibility and shareholder value: An empirical test of the risk management hypothesis. Strategic Management Journal, 30, 425-445.

Goss, D. (2005). Schumpeter's legacy? Interaction and emotions in the sociology of entrepreneurship. Entrepreneurship Theory and Practice, 29(2), 205-218. 
Grant, A. M. (2007). Relational job design and the motivation to make a prosocial difference. Academy of Management Review, 32(2), 393-417.

Grant, A. M. (2008). Does intrinsic motivation fuel the prosocial fire? Motivational synergy in predicting persistence, performance, and productivity. Journal of Applied Psychology, 93(1), 48 .

Grant, A. M., \& Berry, J. W. (2011). The necessity of others is the mother of invention: Intrinsic and prosocial motivations, perspective taking, and creativity. Academy of Management Journal, 54(1), 73-96.

Grimes, M., Williams, T., \& Zhao, E. Y. (2018). Anchors aweigh: The sources, variety, and challenges of mission drift. Academy of Management Review, In press.

Gundry, L. K., Kickul, J. R., Griffiths, M. D., \& Bacq, S. C. (2011). Creating social change out of nothing: The role of entrepreneurial bricolage in social entrepreneurs' catalytic innovations. In Social and sustainable entrepreneurship (pp. 1-24). Emerald Group Publishing Limited.

Headd, B. (2003). Redefining business success: Distinguishing between closure and failure. Small Business Economics, 21(1), 51-61.

Hockerts, K. (2015). How hybrid organizations turn antagonistic assets into complementarities. California Management Review, 57(3), 83-106.

Hoetker, G., \& Agarwal, R. (2007). Death hurts, but it isn't fatal: The postexit diffusion of knowledge created by innovative companies. Academy of Management Journal, 50(2), 446-467.

Humana (2018). http://humanacsr.com/wp-content/uploads/2018/08/156257_CSR-Report2018_080818_INT_HR_Final.pdf. 
Hannan, M. T., \& Freeman, J. (1984). Structural inertia and organizational change. American Sociological Review, 49(2), 149-164.

Hsu, D. K., Wiklund, J., \& Cotton, R. D. (2017). Success, failure, and entrepreneurial reentry: An experimental assessment of the veracity of self-efficacy and prospect theory. Entrepreneurship Theory and Practice, 41(1), 19-47.

Jay, J. (2013). Navigating paradox as a mechanism of change and innovation in hybrid organizations. Academy of Management Journal, 56(1), 137-159.

Jordan, P. J., \& Troth, A. C. (2004). Managing emotions during team problem solving: Emotional intelligence and conflict resolution. Human Performance, 17(2), 195-218.

Josefy, M., Dean, T. J., Albert, L. S., \& Fitza, M. A. (2017). The Role of Community in Crowdfunding Success: Evidence on Cultural Attributes in Funding Campaigns to "Save the Local Theater". Entrepreneurship Theory and Practice, 41(2), 161-182.

Kanov, J. M., Maitlis, S., Worline, M. C., Dutton, J. E., Frost, P. J., \& Lilius, J. M. (2004). Compassion in organizational life. American Behavioral Scientist, 47(6), 808-827.

Katre, A., \& Salipante, P. (2012). Start-up social ventures: Blending fine-grained behaviors from two institutions for entrepreneurial success. Entrepreneurship Theory and Practice, 36(5), 967-994.

Knight, F. H. (1921). Risk, uncertainty and profit. New York: Hart, Schaffner and Marx.

Knott, A. M., \& Posen, H. E. (2005). Is failure good?. Strategic Management Journal, 26(7), $617-641$

Kroeger, A., \& Weber, C. (2014). Developing a conceptual framework for comparing social value creation. Academy of Management Review, 39(4), 513-540. 
Lee, S. H., Yamakawa, Y., Peng, M. W., \& Barney, J. B. (2011). How do bankruptcy laws affect entrepreneurship development around the world?. Journal of Business Venturing, 26(5), $505-520$.

London, T., \& Hart, S. L. (2004). Reinventing strategies for emerging markets: beyond the transnational model. Journal of International Business Studies, 35(5), 350-370.

Low, M. B., \& MacMillan, I. C. (1988). Entrepreneurship: Past research and future challenges. Journal of Management, 14(2), 139-161.

Lupton, R. D. (2012). Toxic charity: How churches and charities hurt those they help, and how to reverse it. New York: HarperCollins.

Lyons, T. S., Alter, T. R., Audretsch, D., \& Augustine, D. (2012). Entrepreneurship and community: The next frontier of entrepreneurship inquiry. Entrepreneurship Research Journal, 2(1).

Mair, J., \& Marti, I. (2006). Social entrepreneurship research: A source of explanation, prediction, and delight. Journal of World Business, 41(1), 36-44.

Mair, J., Robinson, J., \& Hockerts, K. (Eds.). (2006). Social Entrepreneurship (p. 3). New York: Palgrave Macmillan.

McClelland, D. C. (1965). N achievement and entrepreneurship: A longitudinal study. Journal of Personality and Social Psychology, 1(4), 389-392.

McGrath, R. G. (1999). Falling forward: Real options reasoning and entrepreneurial failure. Academy of Management Review, 24(1), 13-30.

McMullen, J. S., \& Bergman Jr, B. J. (2017). Social entrepreneurship and the development paradox of prosocial motivation: A cautionary tale. Strategic Entrepreneurship Journal, 11(3), 243-270. 
McMullen, J. S., \& Shepherd, D. A. (2006). Entrepreneurial action and the role of uncertainty in the theory of the entrepreneur. Academy of Management Review, 31(1), 132-152.

McMullen, J. S., \& Warnick, B. J. (2016). Should we require every new venture to be a hybrid organization?. Journal of Management Studies, 53(4), 630-662.

Miller, T. L., Grimes, M. G., McMullen, J. S., \& Vogus, T. J. (2012). Venturing for others with heart and head: How compassion encourages social entrepreneurship. Academy of Management Review, 37(4), 616-640.

Meyer, M. W., \& Zucker, L. G. (1989). Permanently failing organizations. Sage Publications, Inc.

Miller, D. (1994). What happens after success: The perils of excellence. Journal of Management Studies, 31, 325-358.

Moroz, P. W., Branzei, O., Parker, S. C., \& Gamble, E. N. (2018). Imprinting with purpose: Prosocial opportunities and B Corp certification. Journal of Business Venturing, 33(2), 117-129.

Moss, T. W., Renko, M. Block, E. \& Meyskens, M. (2018). Funding the story of hybrid ventures: Crowdfunder lending preferences and linguistic hybridity. Journal of Business Venturing, 33, 643-659.

Mueller, B. A., Wolfe, M. T., \& Syed, I. (2017). Passion and grit: An exploration of the pathways leading to venture success. Journal of Business Venturing, 32(3), 260-279.

Nili, S. (2011). Humanitarian disintervention. Journal of Global Ethics, 7, 33-46.

Oswick, C., Fleming, P., \& Hanlon, G. (2011). From borrowing to blending: Rethinking the processes of organizational theory building. Academy of Management Review, 36(2), 318-337. 
Pache, A. C., \& Santos, F. (2013). Inside the hybrid organization: Selective coupling as a response to competing institutional logics. Academy of Management Journal, 56(4), 972-1001.

Paolella, L., \& Durand, R. (2016). Category spanning, evaluation, and performance: Revised theory and test on the corporate law market. Academy of Management Journal, 59(1), $330-351$.

Pardales, M. J., \& Girod, M. (2006). Community of Inquiry: Its past and present future. Educational Philosophy and Theory, 38(3), 299-309.

Parhankangas, A., \& Renko, M. (2017). Linguistic style \& crowdfunding success among social \& commercial entrepreneurs. Journal of Business Venturing, 32(2), 215-236.

Parker, S. C. (2018). The economics of entrepreneurship. Cambridge, UK: Cambridge University Press.

Patzelt, H., \& Shepherd, D. A. (2011). Recognizing opportunities for sustainable development. Entrepreneurship Theory and Practice, 35(4), 631-652.

Pearce, I. I., John, A., Fritz, D. A., \& Davis, P. S. (2010). Entrepreneurial orientation and the performance of religious congregations as predicted by rational choice theory. Entrepreneurship Theory and Practice, 34(1), 219-248.

Pelled, L. H., Eisenhardt, K. M., \& Xin, K. R. (1999). Exploring the black box: An analysis of work group diversity, conflict and performance. Administrative Science Quarterly, $44(1), 1-28$.

Peredo, A. M., \& Chrisman, J. J. (2006). Toward a theory of community-based enterprise. Academy of Management Review, 31(2), 309-328. 
Peredo, A. M., Haugh, H. M., \& McLean, M. (2017). Common property: Uncommon forms of prosocial organizing. Journal of Business Venturing, 1016.

Perlow, L., \& Weeks, J. (2002). Who's helping whom? Layers of culture and workplace behavior. Journal of Organizational Behavior, 23(4), 345-361.

Renko, M. (2013). Early challenges of nascent social entrepreneurs. Entrepreneurship Theory and Practice, 37(5), 1045-1069.

Schlaerth, A., Ensari, N., \& Christian, J. (2013). A meta-analytical review of the relationship between emotional intelligence and leaders' constructive conflict management. Group Processes \& Intergroup Relations, 16(1), 126-136.

Schuller, M. (2012). Killing with kindness: Haiti, international aid, and NGOs. New Brunswick, NJ: Rutgers University Press.

Scott, W. R. \& Davis, G. F. (2016). Organizations and organizing: Rational, natural and open systems perspectives. New York: Routledge.

Shane, S., Locke, E. A., \& Collins, C. J. (2003). Entrepreneurial motivation. Human Resource Management Review, 13(2), 257-279.

Shane, S., Locke, E. A., \& Collins, C. J. (2003). Entrepreneurial motivation. Human Resource Management Review, 13(2), 257-279.

Shepherd, D. A. (2015). Party On! A call for entrepreneurship research that is more interactive, activity based, cognitively hot, compassionate, and prosocial. Journal of Business Venturing, 30(4), 489-507.

Shepherd, D. A. (2003). Learning from business failure: Propositions of grief recovery for the self-employed. Academy of Management Review, 28(2), 318-328. 
Shepherd, D. A. (2009). Grief recovery from the loss of a family business: A multi-and mesolevel theory. Journal of Business Venturing, 24(1), 81-97.

Shepherd, D. A., \& Patzelt, H. (2015). Harsh evaluations of entrepreneurs who fail: The role of sexual orientation, use of environmentally friendly technologies, and observers' perspective taking. Journal of Management Studies, 52(2), 253-284.

Shepherd, D. A., \& Patzelt, H. (2011). The new field of sustainable entrepreneurship: Studying entrepreneurial action linking "what is to be sustained" with "what is to be developed". Entrepreneurship Theory and Practice, 35(1), 137-163.

Shepherd, D. A., Wiklund, J., \& Haynie, J. M. (2009). Moving forward: Balancing the financial and emotional costs of business failure. Journal of Business Venturing, 24(2), 134-148.

Shepherd, D. A., \& Williams, T. A. (2014). Local venturing as compassion organizing in the aftermath of a natural disaster: The role of localness and community in reducing suffering. Journal of Management Studies, 51(6), 952-994.

Shepherd, D. A., \& Williams, T. A. (2018). Hitting rock bottom after job loss: Bouncing back to create a new positive work identity. Academy of Management Review, 43(1), 28-49.

Shepherd, D. A., \& Williams, T. A. (2019). Spontaneous Venturing : An Entrepreneurial Approach to Alleviating Suffering in the Aftermath of a Disaster. Cambridge, MA: MIT Press.

Shepherd, D. A., Williams, T., Wolfe, M., \& Patzelt, H. (2016). Learning from entrepreneurial failure. Cambridge University Press.

Short, J. C., Moss, T. W., \& Lumpkin, G. T. (2009). Research in social entrepreneurship: Past contributions and future opportunities. Strategic Entrepreneurship Journal, 3(2), 161194. 
Simanis, E., \& Hart, S. (2008). Beyond selling to the poor: building business intimacy through embedded innovation. Johnson School of Management.

Smith W.K., Besharov M.L. (2018). Bowing before dual gods: How structured flexibility sustains organizational hybridity. Administrative Science Quarterly, In Press

Smith, W. K., Gonin, M., \& Besharov, M. L. (2013). Managing social-business tensions: A review and research agenda for social enterprise. Business Ethics Quarterly, 23(3), 407442.

Smith, W. K., \& Tracey, P. (2016). Institutional complexity and paradox theory: Complementarities of competing demands. Strategic Organization, 14(4), 455-466.

Tobias, J. M., Mair, J., \& Barbosa-Leiker, C. (2013). Toward a theory of transformative entrepreneuring: Poverty reduction and conflict resolution in Rwanda's entrepreneurial coffee sector. Journal of Business Venturing, 28(6), 728-742.

Tracey, P., Phillips, N., \& Jarvis, O. (2011). Bridging institutional entrepreneurship and the creation of new organizational forms: A multilevel model. Organization Science, 22(1), 60-80.

Ucbasaran, D., Shepherd, D. A., Lockett, A., \& Lyon, S. J. (2013). Life after business failure: The process and consequences of business failure for entrepreneurs. Journal of Management, 39(1), 163-202.

Van Dyne, L., \& LePine, J. A. (1998). Helping and voice extra-role behaviors: Evidence of construct and predictive validity. Academy of Management Journal, 41(1), 108-119.

Venkataraman, S. (1997). The distinctive domain of entrepreneurship research. Advances in Entrepreneurship, Firm Emergence and Growth, 3(1), 119-138. 
Venkataraman, S., Sarasvathy, S. D., Dew, N., \& Forster, W. R. (2012). Reflections on the 2010 AMR decade award: Whither the promise? Moving forward with entrepreneurship as a science of the artificial. Academy of Management Review, 37(1), 21-33.

Weick, K. E. (1989). Theory construction as disciplined imagination. Academy of Management Review, 14(4), 516-531.

Weick, K. E. (1979). The social psychology of organizing. Readon, MA: Addison-Wesley.

Wiklund, J., Baker, T., \& Shepherd, D. (2010). The age-effect of financial indicators as buffers against the liability of newness. Journal of Business Venturing, 25(4), 423-437.

Williams, T. A., Gruber, D., Sutcliffe, K., Shepherd, D. A., \& Zhao, E. Y. 2017. Organizational response to adversity: Fusing crisis management and resilience research streams. Academy of Management Annals, 11(2): 733-769.

Williams, T. A., \& Shepherd, D. A. 2016a. Building resilience or providing sustenance: Different paths of emergent ventures in the aftermath of the Haiti earthquake. Academy of Management Journal, 59(6): 2069-2102.

Williams, T. A., \& Shepherd, D. A. 2016b. Victim entrepreneurs doing well by doing good: Venture creation and well-being in the aftermath of a resource shock. Journal of Business Venturing, 31(4): 365-387.

Williams, T. A., \& Shepherd, D. A. 2018. To the rescue!? Brokering a rapid, scaled and customized compassionate response to suffering after disaster. Journal of Management Studies, 55(6): 910-942.

Wood, M. S., \& McKinley, W. (2010). The production of entrepreneurial opportunity: a constructivist perspective. Strategic Entrepreneurship Journal, 4(1), 66-84. 
Wry, T., \& York, J. G. (2017). An identity-based approach to social enterprise. Academy of Management Review, 42(3), 437-460.

Wry, T., \& Zhao, E. Y. (2018). Taking Trade-offs Seriously: Examining the Contextually Contingent Relationship Between Social Outreach Intensity and Financial Sustainability in Global Microfinance. Organization Science. In Press

Zahra, S. A., Gedajlovic, E., Neubaum, D. O., \& Shulman, J. M. (2009). A typology of social entrepreneurs: Motives, search processes and ethical challenges. Journal of Business Venturing, 24(5), 519-532.

Zahra, S. A., \& Wright, M. (2016). Understanding the social role of entrepreneurship. Journal of Management Studies, 53(4), 610-629.

Zervas, G., Proserpio, D., \& Byers, J. (2016). The rise of the sharing economy: estimating the impact of Airbnb on the hotel industry. Boston U. School of Management Research Paper No. 2013-16. Available at SSRN 2366898.

Zhao, E. Y., \& Lounsbury, M. (2016). An institutional logics approach to social entrepreneurship: Market logic, religious diversity, and resource acquisition by microfinance organizations. Journal of Business Venturing, 31(6), 643-662.

Zhao, E. Y., \& Wry, T. (2016). Not all inequality is equal: Deconstructing the societal logic of patriarchy to understand microfinance lending to women. Academy of Management Journal, 59(6), 1994-2020. 
Figure 1a. Conceptualization of Hybrid Relativity

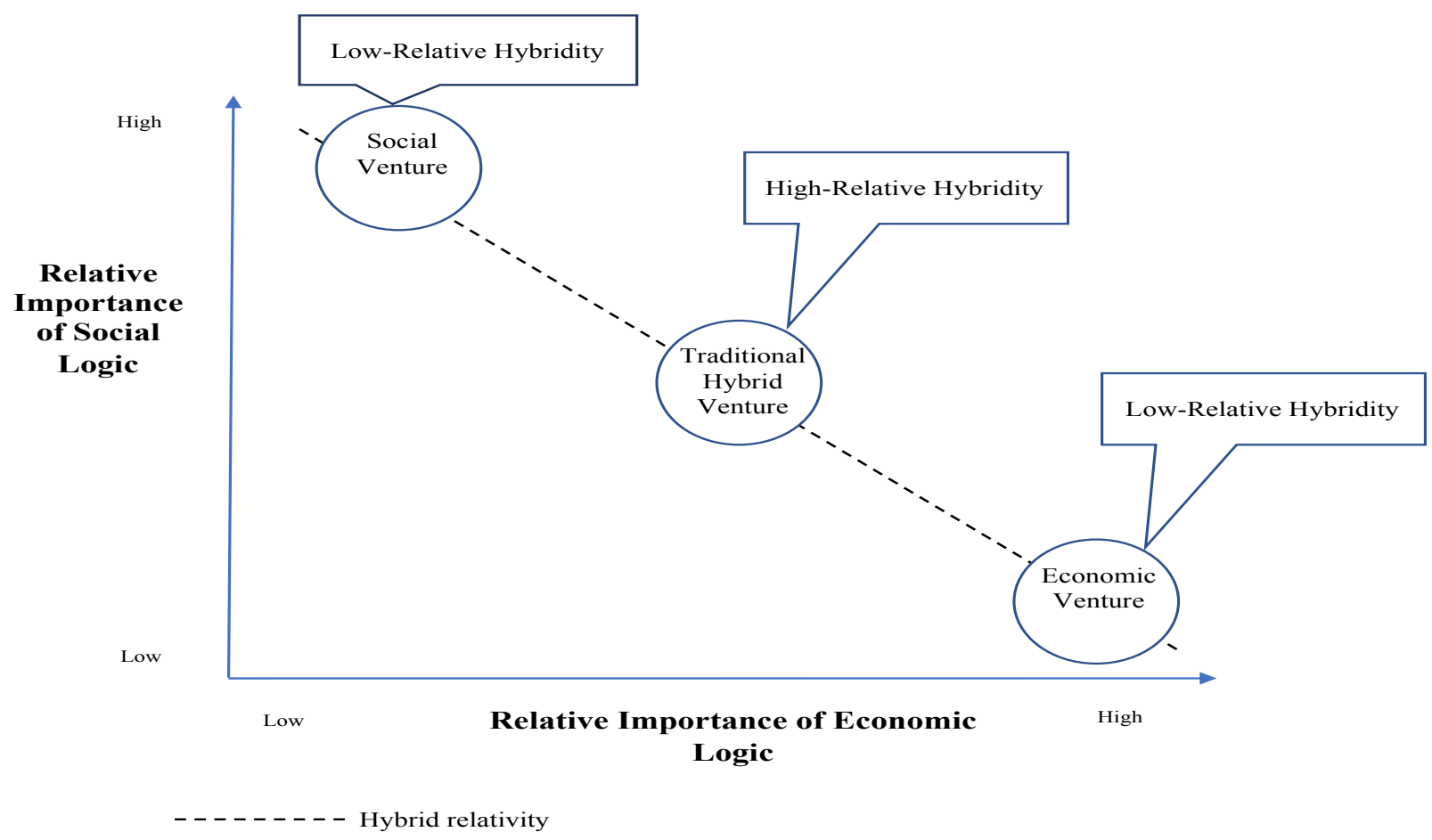

Figure 1b. Conceptualization of Hybrid Intensity

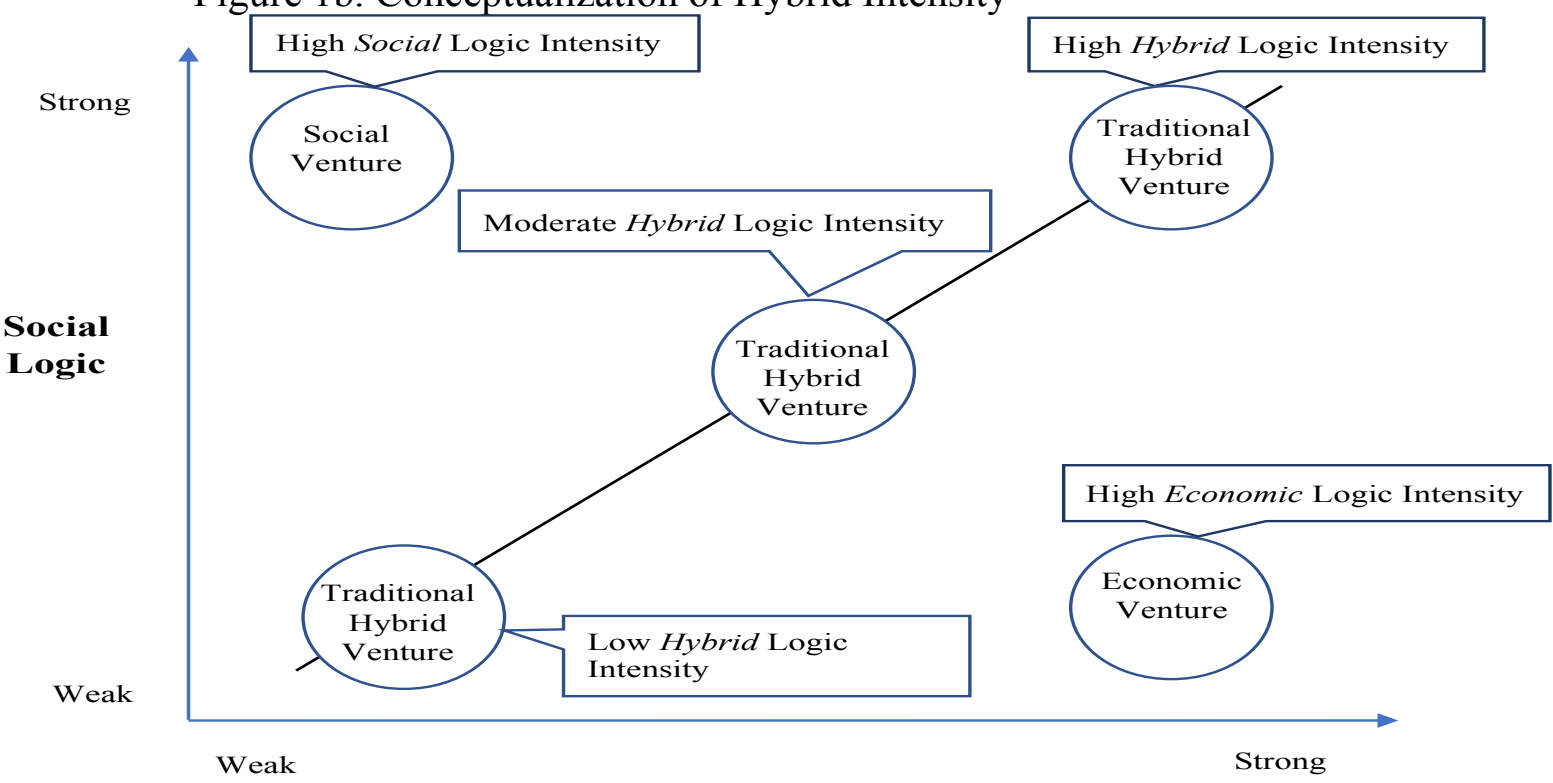

Economic Logic

Hybrid logic intensity 
Figure 1c. Conceptualization of the Degree of Hybridity

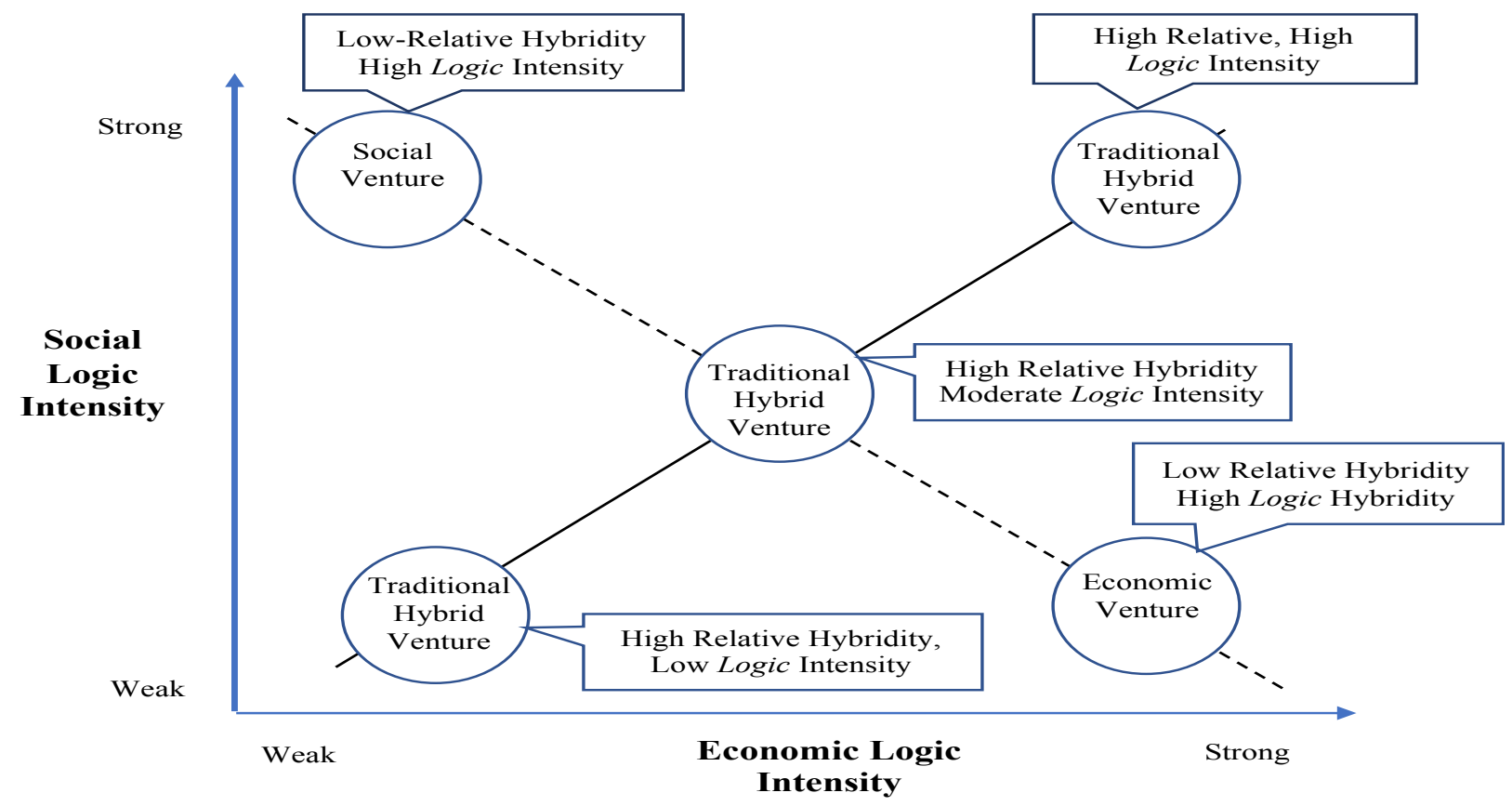

Hybrid logic intensity

- - - - - - - Hybrid relativity

Figure 1d. Degree of Hybridity Curves

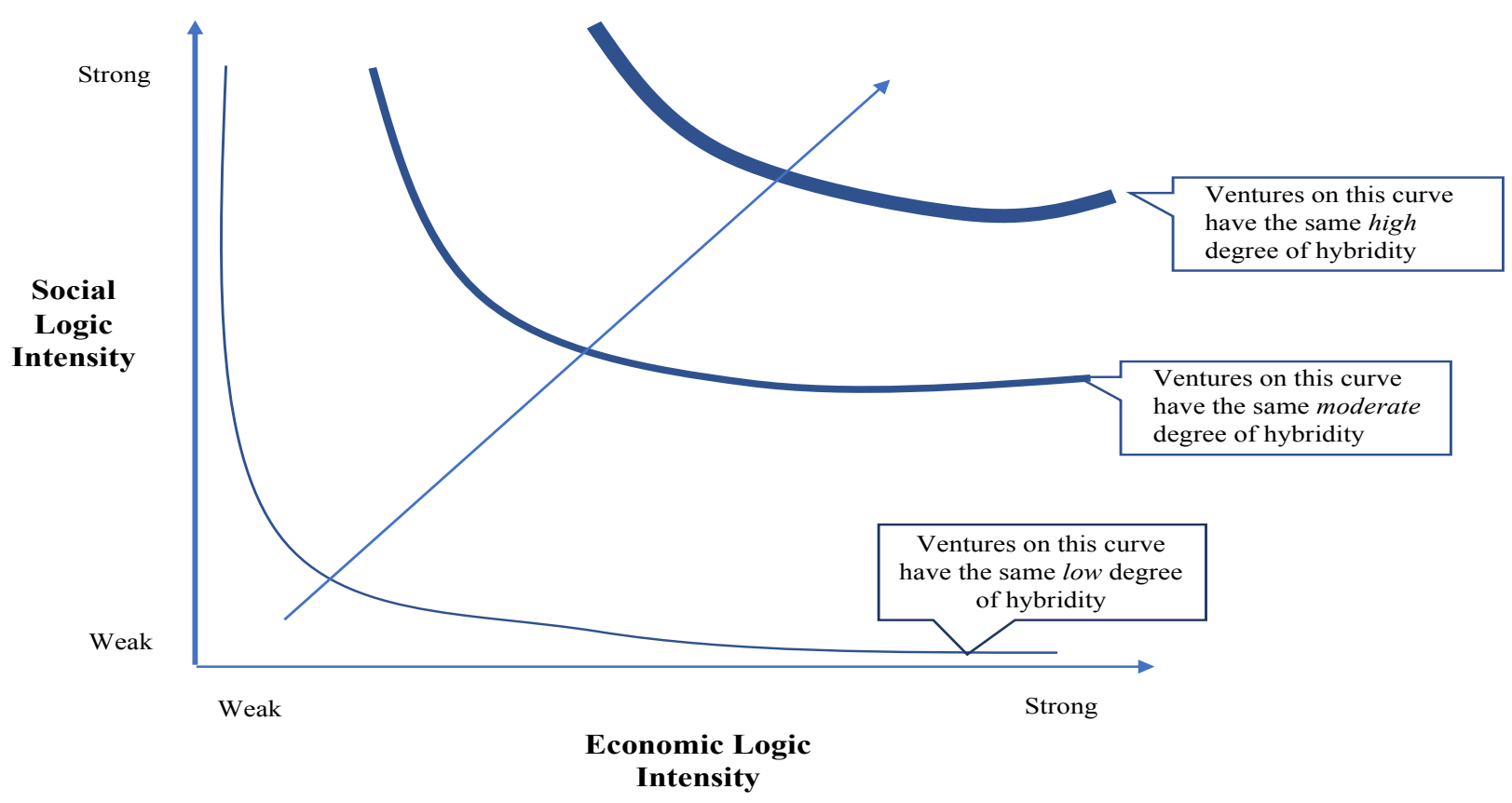


Figure 2. A Framework for Future Research on Hybrid Organizing and Entrepreneurship

\section{Entrepreneur}

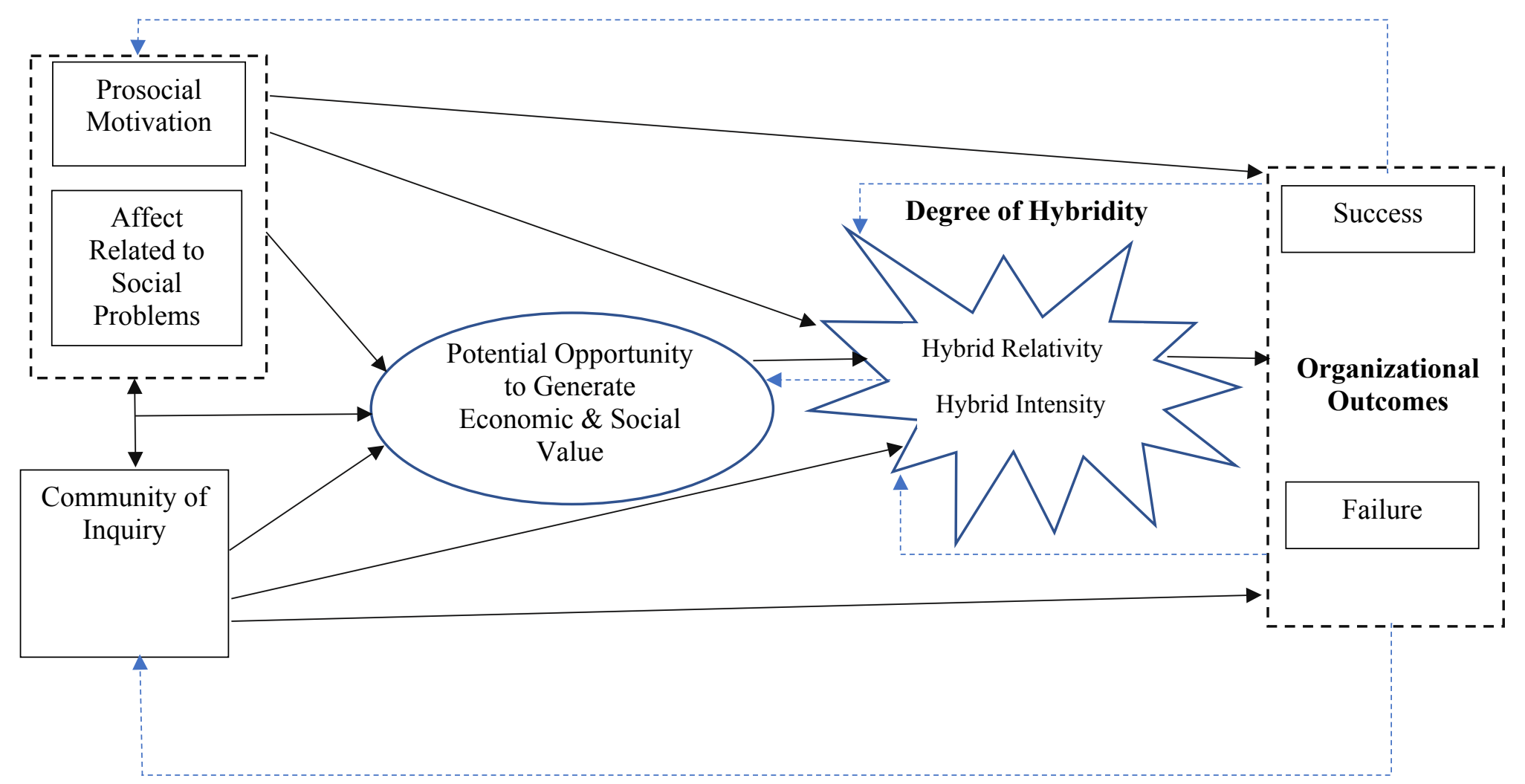




\begin{abstract}
Author biographies
Dean A. Shepherd (dshephe1@nd.edu) is the Ray and Milann Siegfried Professor of Entrepreneurship at the Mendoza College of Business, Notre Dame University. His research investigates decision making involved in leveraging cognitive and other resources to act on opportunities and processes of learning from experimentation that lead to high levels of individual and organizational performance.
\end{abstract}

Trenton Alma Williams (trenwill@iu.edu) is an Assistant Professor at the Indiana University, Kelley School of Business. His research includes venture emergence under extreme resource constraint, value creation in its many forms (hybrid organizing, compassionate venturing, and so forth), resourcefulness, resilience, emergent responses to disasters, and decision-making under uncertainty.

Eric Yanfei Zhao (ericzhao@indiana.edu) is an Assistant Professor of Management and Entrepreneurship at the Indiana University, Kelley School of Business. His research interest lies at the intersection of strategic management, organization theory, and entrepreneurship, with a particular focus on strategic paradoxes, investigating how various types of organizations function and succeed under complex institutional and organizational challenges. 